\title{
Rethinking of Curriculum for the Senior Staff Course of Bangladesh Public Administration Training Centre: An Empirical Analysis
}

Md. Zohurul Islam

Assistant Professor, Institute of Governance Studies (IGS) BRAC University, Bangladesh Email: zohur68@gmail.com

Md. Shafiqul Haque

Deputy Director, Public Administration Training Centre (BPATC), Bangladesh

Email: shafiqulh@gmail.com

Md. Abdul Mannan

Email: mamannan77@gmail.com

Accepted 20 January 2014

One of the mandates of Bangladesh Public Administration Training Centre (BPATC) is to develop human capital of senior level civil servants of Bangladesh. This study has identified the development needs of the Joint Secretaries of Bangladesh Civil Service in order to facilitate knowledge and skills through Senior Staff Course (SSC) organized by BPATC. This study has used quantitative research approach. Data were collected from different levels of respondents that include officers of the rank of Joint Secretary, Additional Secretary and Secretary. The results have yielded seven thematic areas, in respect of knowledge and skills where Joint Secretaries are required to develop and with these seven thematic areas course contents need to be developed to achieve present and future priorities of the Government of Bangladesh.

Key words: Senior executive development, training curriculum, capacity development, need assessment

\section{Introduction}

Effective and efficient service delivery to the people is a constitutional obligation of every public servant of Bangladesh (GoB, 2003). Level of satisfaction of service recipients - the citizens - is one of the key indicators of the effectiveness of service delivered by the public servants. Unfortunately, citizens' perception about public service of Bangladesh is quite unfavourable (Haque, 2001). Various surveys, conducted a decade ago, indicated that the 
majority of the citizens stereotypically viewed that public service of the country is relatively over centralised, unaccountable, unresponsive, inefficient, overpaid, coercive, unethical, and rent-seeking (World Bank, 1996; Zafarullah et al., 1997 cited in Haque, 2001:103). In Bangladesh, public satisfaction with essential public sector services is quite low, and the common citizens are quite unhappy with the indifferent, discourteous, arrogant, and corrupt behavior of public servants (Zafarullah et al., 1997 cited in Haque, 2001:104). The quality of major public sector services, for example, state-run primary education, healthcare and general infrastructure, is not up to the mark to 63-73 percent of citizens (Haque, 2001:105). Over the decade, citizens' perception, however, about public service has not improved rather remains significantly negative (Jahan, 2006). The reasons for this impression are not a simple equation; there may be many factors responsible for this situation. One reason, perhaps, is the lack of a specific strategic approach of the government which, in turn, has been caused by lack of proper initiative at national consensus building on core governance issues. This is exemplified by worst infrastructure ranks (Bangladesh ranks $126^{\text {th }}$ position in 133 nations as mentioned in the Global Competitiveness Report 2010 and lack of improvements in education, human capital and corruption indicators ${ }^{1}$ low labour productivity outside agriculture, fragile energy and water security, climate change, and weak trade logistic index $\left(\mathrm{LPI}^{2}\right)$. According to World Bank, Bangladesh holds $79^{\text {th }}$ position among 155 countries in terms of the 2010 LPI (Ahmed, 2010). Hence, the senior civil servants, as a part of the policy planners of the country, can play a vital role to address the said core governance issues in order to ensure effective and efficient service delivery to the citizens.

\section{Historical Overview of BPATC and Senior Staff Course (SSC) in Bangladesh}

After the independence of Bangladesh, the in-service training of the senior civil servants had been suspended for a long time because of non-existence of any training institutes for them at the time. Although the necessity of such training was being increasingly felt for long, eventually Bangladesh Administrative Staff College (BASC) was established on 3 June 1977. But in the history of training institutes of Bangladesh, the BASC was the shortest lived training

\footnotetext{
${ }^{1}$ The Daily Star, 09 September 2009.

${ }^{2}$ The LPI is the weighted average of the country scores on the six key dimensions: (a) efficiency of the clearance process by border control agencies, including customs, (b) quality of trade and transport related infrastructure, (c) ease of arranging competitively priced shipments, (d) competence and quality of logistics services, (e) ability to track and trace consignments, and (f) timeliness of shipments in reaching destinations within the scheduled or expected delivery time.
} 
institute of the country. Only after seven years of functioning, the BASC along with three other training institutes was merged into Bangladesh Public Administration Training Centre (BPATC) in 1984 vide a Presidential Ordinance.

The standard of training for the senior civil servants set by BASC in 1977 and also what was inherited from erstwhile PASC, Lahore did not get lost after BASC's merger into BPATC in 1984. The BPATC continued the training of the senior civil servants, although there have been many changes in terms of course duration and other aspects of the training.

According to Wahiduzzaman (1987) as well as Hossain and Imam (2002), it is evident that before the establishment of BPATC, the then Bangladesh Administrative Staff College (BASC) used to arrange training course for the senior civil servants under the title "Regular Training Course on Administration and Management". The course was of three months in duration. The training methodology followed by BASC for this training programme included 1) Lecture and Discussions 2) Syndicate Studies 3) Seminar Studies 4) Field Research 5) Visit to a neighbouring foreign country and 6) Case Studies including role play and sensitivity programmes. BASC started holding this course from 1977-78 sessions. Depending upon training needs and changes in the policy of the Government, the course contents at BASC varied from course to course. However, the areas the courses covered used to include the following seven parts:

Part-I: Foundation Lectures on a. Bangladesh Environment (Land, People, Language and Culture), b. Principles and Theories of Development Administration, c. Principles and Theories of Development Economics, d. Science and Administration, e. Sociology, Psychology and Administration. Part-II: Administrative Structures and Processes used to be delivered through syndicate covering the areas of a. Organization: Theory and Practice, b. Principles and Theories of Development Administration, c. Principles and Theories of Financial Administration and Management, d. Planning and Development. Part-III: Programme Administration was again an area of syndicate that used to cover a. Agriculture, b. District Administration, c. Education, d. Health, e. Industry, f. Local Government, g. Management of Public Corporations, h. Population and Family Planning, i. Rural Development and Rural Institutions. Part-IV: Senior Administrator-His Roles and Responsibilities was another syndicate work. Part-V was a Field Study. Part-VI was on Writing a Seminar Paper on topics relating to a. Development Administration and b. Development Economics. Finally, Part-VII: Short Visit to a Foreign Country was for a comparative study of problems and processes in some specific fields of administration and development.

The present course contents as of now ( $57^{\text {th }}$ SSC) have been changed significantly compared with BASC course of this type. At present there are eleven modules- Module 1: Public Administration and Governance; Module 2: Review of Public Policies; Module 3 : Globalization and International Negotiations; Module 4: Leading Issues in Economic 
Development; Module 5: Environment and Sustainable Development; Module 6: Financial Management; Module 7: English Language Skills; Module 8: ICT and e-Government Management; Module 9: Physical Conditioning and Games; Module 10: Syndicate Work on the Theme of the Course; Module 11: Extension Lectures. Foreign study tour is still a part of the SSC but usually such a tour is organized after a few months of the completion of the course and that is why the study tour does not have any direct bearing upon successful passing out of the course.

In contrast, Hossain and Imam (2002) opined that the "Regular Training on Administration and Management” at BASC had three basic shortcomings: i. there was no focus (i.e. central theme) of the course; ii. modular approach was not strictly followed; and iii. foreign study tour was not regular. The "Regular Training on Administration and Management" held at BASC used to have the a number of major objectives including a) to help the participants achieve a higher level of competence enabling them to cope with the challenging demands of a changing society, to think and analyze critically and to decide promptly and unambiguously; b) to acquaint the participants with theoretical framework of development policies and their applicability in the context of Bangladesh; c) to relate that framework to an appreciation of the various aspects of socio-economic development of the country; and d) to enrich their overall analytical abilities.

Thus, this article aims at illustrating both core and specialized roles of Joint Secretaries of Bangladesh Civil Service in order to update the existing curriculum of Senior Staff Course. The main objective of the article is to highlight the learning and development needs of the newly promoted Joint Secretaries in order to enable them to play their new roles effectively.

\section{Methods and materials}

The study has been conducted through an open-ended questionnaire survey among Joint Secretaries, Additional Secretaries, and Secretaries. Individual survey, e-mail survey and workshops were arranged to collect data from the respondents. Collected data were analyzed with quantitative, qualitative and graphical terms to identify the development needs of the Joint Secretaries of BCS to carry out the government's current and future priorities.

\section{Target population}

For this study, the target population was drawn from government officials, who are civil servants of Bangladesh Government holding positions as Joint Secretaries. 


\section{Sampling procedure}

Firstly, we considered only officials having the rank and status of Joint Secretary belonging to Bangladesh Civil Service (BCS), who are eligible for SSC as well. For this study, we considered participants of $54^{\text {th }}, 55^{\text {th }}, 56^{\text {th }}$ and $58^{\text {th }}$ SSCs as respondents. Respondents were selected purposively.

Supervisory officials of a Joint Secretary, for example, officials with the rank and status of Secretary and Additional Secretary of different ministries/divisions were also considered as respondents. We also considered the participants (Additional Secretaries) of $5^{\text {th }}$ Policy Planning and Management Course conducted by BPATC as respondents for this study. Here, the respondents were also selected purposively.

\section{Questionnaire development and survey}

Before collecting primary data we developed three sets of checklists/questionnaires for collecting data from the respondents. Questionnaire prepared for the Joint Secretaries was pretested under a pilot survey participated by 24 participants of $54^{\text {th }}$ Senior Staff Course. The same instruments were used to collect data from other Joint Secretaries participating in $54^{\text {th, }}$ $55^{\text {th }}, 56^{\text {th }}$ and $58^{\text {th }}$ SSCs. Thus, the number of respondent Joint Secretaries stood 86. Opinions on SSC were also solicited from the Additional Secretaries, participants of $5^{\text {th }}$ Policy Planning and Management Course who had undergone training at BPATC. Out of 18 participants, 11 responded to the questionnaire distributed to them. To get opinions from the Secretaries and Additional Secretaries, another set of questionnaire was developed and sent to the Secretaries and Additional Secretaries of different ministries and divisions. Initially, four Secretaries and six Additional Secretaries sent back the filled-in questionnaire. Getting poor response, we again sent the questionnaire to them by post and electronically (e-mail). As a result, we received 23 more filled-in questionnaires. For secondary data, we consulted relevant research reports, books and documents. The respondents' ranks and status are presented in Table 1.

Table 1: Ranks and status of the respondents

\begin{tabular}{lc}
\hline Position & Number \\
\hline Secretary & 14 \\
Additional Secretary & 19 \\
Joint Secretary & 86 \\
\hline Total & 119 \\
\hline
\end{tabular}


Rethinking of the Curriculum for the Senior Staff Course of BPATC

\section{Expert opinion}

We also solicited expert opinions at different stages of study. Experts include one former Secretary and one current Secretary to the Government, one national expert on training and consultancy, and one international consultant on training.

\section{Data analysis}

Firstly, we scrutinized all collected primary data which was indeed a difficult task as the data were mostly qualitative in nature. There were hundreds of entries against the questions related to common tasks of the Joint Secretaries, current and future priorities, and required knowledge and skills to address the set priorities. For better understanding and analysis, we categorized all inputs according to five thematic areas such as 'human resource', 'international linkage and relationship', 'organization /institution', 'policy' and 'service delivery'. After the first validation workshop with the participants of $56^{\text {th }}$ SSC, we identified two new themes such as 'project management' and 'financial management'. Accordingly, we clustered the responses into seven thematic areas.

\section{Pilot survey}

A pilot survey was done to fine-tune the research instruments and to develop the interview procedure. It was conducted with 18 Joint Secretaries who were, at the time of pilot study, working in different organizations and participating in Senior Staff Course at BPATC.

\section{Results}

\section{Respondents' place of posting (pilot survey)}

First, a questionnaire was distributed among the participants of $54^{\text {th }}$ Senior Staff Course organized by BPATC. There were 19 Joint Secretaries and equivalent officials in the course. Among them 18 responded to the questionnaire of which one represented defence service as a small number of officers from Armed Forces of Bangladesh also participate in SSC alongside the BCS officers. Respondent participants represented 18 different ministries/ departments/ corporations and so on (Annex 1). 
Rethinking of the Curriculum for the Senior Staff Course of BPATC

\section{Length of service of the respondents}

Among the 18 respondents, the largest shares of respondents (66.7 \%) were from 1-2 years of their service length at present place of position. And rest of the respondents (33.3\%) was from more than that of their service length at the level of Joint Secretary (Annex 2).

\section{Field of experience}

A question was asked to assess the senior civil servants' strength of field experiences. Ten fields of experiences were identified as their strengths. The highest number of the respondents had identified their experience in 'field administration'. The second highest number had their experience in 'personnel management'. Experiences on 'financial management', 'regulatory issues' and 'policy formulation' have received same weightage from the respondents. More or less, other areas of experience were also important for day to day work at their workplace (Annex 3).

\section{Identified common and specific tasks at office}

An open ended questionnaire was distributed to the respondents in regard to identifying specific tasks, which are commonly practiced at office. The identified common and specific tasks done by a Joint Secretary were broadly grouped into six major themes (Annex 4). Among the major themes, human resources (HR) theme scored highest value (20), which consists of 'administrative work' and 'human resource development (HRD)'. Financial management (FM) and project management (PM) were also identified as important themes. Moreover, policy theme (4) was equally important for the senior level officers of government. Thus, the research found that the common important tasks of a Joint Secretary (JS) at office were related to HR, policy making, financial matter/management (FM), project management (PM), and international linkage and relationship (ILR) as a whole.

\section{Identified current priorities of government}

Annex 5 shows some major areas of government functions that have been identified as priorities by the respondents through open ended questionnaires. Multiple responses have been received from 18 respondents. They have identified as many as 20 areas as current priorities of the government. Priority areas were clustered into five themes. Among the five themes, Policy got highest score with multiple response (36) which includes 'poverty alleviation', 'energy security', 'population control', 'disaster management', 'food production', 'environment', 'infrastructure development', 'agricultural development' and so on. The theme that received the 
second highest responses (25) was service delivery. Service delivery (SD) theme covers some items namely 'ICT', 'traffic control', 'reduce corruption', 'law and order', 'food security' and so on.

\section{Identified future priories of the government}

The respondents were asked to identify some areas as priorities that need to be addressed for the next five years. A number of multiple responses were received from 18 respondents. Different 20 issues were identified as future priorities of the government. Findings have been clustered into five thematic areas. They are HR; organization; international negotiation; policy and service delivery themes. Annex 6 shows as per future priorities 'policy' as a major theme got highest score and 'policy' covers 'infrastructure'; 'poverty and energy', 'climate change', 'population control', 'social security', 'land use policy', 'water policy', 'natural resource policy' and 'decentralizing administration'.

Service delivery theme got the second highest score. As the national priorities, the senior level civil servants must understand the process of service delivery system, and they must be capable to handle all sorts of service delivery to the citizen. The service delivery theme includes 'breaking the market syndicate', 'food security', 'law and order', 'ICT and egovernance', 'minimizing corruption' and 'ensuring good governance'.

The third highest score was obtained by HR theme. HR theme covers 'market based salary for the public servants', 'education and HRD', 'skills for overseas employment' and 'employment generation'. Moreover, respondent Joint Secretaries also identified international linkage and relationship theme as a future priority to the government (Annex 6).

\section{Knowledge expected from the course}

The senior executives of Bangladesh Government were asked to identify the knowledge they expected to obtain from SSC. They identified some important areas that would be very much useful for further preparation of SSC curriculum/contents. The list of topics/contents is presented in Annex 7. The 19 identified topics are clustered into five major themes, these are: human resource, international linkage and relationship, policy, financial management and service delivery.

Emphasis was given on 'policy' theme. Here 'policy' theme includes 'important policies', 'policy formulation', 'development administration and governance studies', 'development economic policy', 'climate change policy', 'natural resource policy', and 'migration policy'. The second theme is identified as per respondents' response to knowledge on 'service delivery'. Therefore, senior level civil servants do expect knowledge on service 
delivery from SSC. Service delivery theme covers eleven items and of them important items are 'quick delivery of service', 'TQM'; and 'ICT and e-governance'.

ILR theme covers eight issues such as bi-/multilateral negotiation, English language and public private partnership (PPP). HR theme includes 'drafting of rules and laws' 'competency framework', 'strategic management' and 'professionalism tools'. Moreover, the respondents identified 'financial management' theme as well. And financial management theme covers 'public procurement' and 'fiscal policy'.

\section{Skill development expected from Senior Staff Course}

There was an open ended question for the senior executives regarding expectation on skill development from SSC in order to address the present and future priorities of the government. Multiple responses were received and clustered into seven major themes (Annex 8). Organization/institution theme got the highest score which include 'leadership skill', 'writing reports and minutes', and 'decision making and problem solving'. International linkage and relationship theme got second highest score which covers 'bi-/multilateral negotiation skill', 'communicative English' and PPP. Service delivery theme considers 'ICT' and 'TQM'. Policy theme includes 'policy drafting and formulation'. HR takes account of 'management and motivation skill'; and 'performance based management'. In regard to financial management, one component is extracted which is 'public procurement' and project management theme includes one component- 'project evaluation and implementation'.

\section{Organizational needs to cope with government priorities}

Apart from individual expectations from SSC, there was a question on organizational needs which would help to pursue government's present and future priorities. A number of areas/issues were identified by the respondents (Annex 9). Among the major themes, service delivery (SD) ranks first. This service delivery theme consists of 'speedy disposal of complaints', 'office automation' and 'citizen centric service'. 'Financial management' gets second highest score followed by 'organization/institution theme'. Therefore, to cope with government priorities, senior level civil servants have to have more capability with service delivery system as well as competency with financial management and organizational development.

\section{Major areas for capacity building of senior executives and organizational development}

By using a research instrument, respondents were asked to identify some of capacity building areas, where they are supposed to develop their knowledge and skills. To ensure capacity 
building the major themes they identified were HR and policy. Moreover, they mentioned that international linkage and relationship theme, service delivery and financial management are also important areas for capacity development in regards to individual development as well as organizational development.

They are experienced in diversified areas such as field administration, personnel management, regulatory functions and policy formulation. Common important tasks of respondent Joint Secretaries at their offices are regarding HR, policy making, financial matter and project management theme. Current priorities of the government are inclined to policy, service delivery and human resource theme. Future priorities, as identified by the respondent Joint Secretaries, are again attached to policy, service delivery and human resource theme. In order to address the current priorities of the government, the respondent Joint Secretaries obtain some knowledge and skills which are mainly related to policy, service delivery, international linkage and relationship and human resource theme. Apart from individual expectations from SSC, they have maintained some organizational needs which would help to pursue government's present and future priorities. These needs are attached to service delivery, financial management, organization/institution and human resource theme. They further emphasized participatory process/methods of conducting the Senior Staff Course to make it an effective one.

\section{Experiences of senior executives}

The senior executives identified their experiences in nine different fields (Annex 10). The five important areas of experiences of Joint Secretaries include field administration (65.0\%), personnel management (60.0\%), project management (45.0\%), financial management $(35.0 \%)$ and policy formulation/drafting (35.0\%). The rest four areas of experiences are regulatory issues (20.0\%), land management (10.0\%), e-governance $(10.0 \%)$ and bi-/multilateral negotiation (5.0\%).

It has been identified that majority of Secretaries and Additional Secretaries have expertise on different areas of which the five important areas include project management (58.0\%), personnel management (49.0\%), financial management (49.0\%), land management $(40.0 \%)$ and policy formulation/ drafting (40.0\%). A significant number of them have expertise on regulatory issues (33.0\%), bi-/multilateral negotiation (27.0\%) and e-governance $(27.0 \%)$. Only 3 (9.0\%) have experience on international commerce (Annex 10).

\section{Regular tasks performed by the senior executives}

In response to the question on their most important routine tasks, 17 senior executives identified different tasks while the rest three did not respond as they were officers on special 
duty (OSD). Joint Secretaries were asked to mention their important routine tasks. Accordingly, they have identified as many as 15 types of tasks, which include: personnel management, negotiation, attending Parliamentary Standing Committee meetings, policy formulation, providing health service, monitoring and evaluation, and financial management. All these tasks are related to six thematic areas (Annex 11). Human resource is identified as the most focused thematic area followed by financial management and project management. Other routine tasks include organization, policy, international linkage and relationship and service delivery themes.

Secretaries were also asked to identify common tasks usually performed by a Joint Secretary working under them. In response to this question they identified as many as 50 types of tasks (Annex 12), some of which includes personnel administration and management, regulatory issues and general administration, supervision, monitoring and coordinating activities of the department including field offices, bi-lateral/multilateral negotiation and signing MOU with different organizations, representing and coordinating intra and inter agencies, PPP, maintaining relationship with mass media and other stakeholders, policy formulation and analysis, drafting laws, rules and regulations, project management, financial management, preparation and supervision of budget and expenditure, and public procurement.

Identified 50 types of tasks are clustered (Annex 12) into six thematic areas. They are: Human resource management identified as the most focused thematic area followed by organization/institution, policy, international linkage and relationship, project management, and financial management.

\section{Current/short-term priorities of the ministry/organization}

Senior Executives (respondents) were asked to identify some of tasks, which are related to current priority of government and they have identified as many as 28 current priority items of their ministries/organizations.

Identified important current priorities are: skilled manpower, recruitment, mass awareness on livestock and fisheries, efficient and effective negotiation in obtaining foreign aid, the Padma Multipurpose Bridge Project, Elevated Express Way Project, developing infrastructure facilities for games and sports, simplification of pension policy, formulation and updating of external economic policy for achieving/maintaining targeted economic growth, formulating civil service act, ICT and e-governance, and effective monitoring of foreign funded projects.

Current priorities identified by respondents are again linked to five thematic areas (Annex 13). The most focused current priority is related with policy theme followed by international linkage and relationship theme, service delivery theme, human resource management theme and project management theme. 
Senior executives were also requested to identify the current priorities of their ministries/organizations. They identified as many as 75 issues/items as current priority. The important priorities take account of: HR planning and development of ICT, procurement and recruitment of project staff, creating new employment, equipping the civil servants to face the challenges of 21st century, bi-lateral/multilateral negotiation, formulating and signing MOU with different organizations, attract FDI and aid mobilization, formulating rules/regulations and establishing economic zones, coordination of inter-ministerial matters, strengthening capacity and quality of BBS and maintaining relationship with mass media, policy formulation and analysis, drafting laws, rules and regulations in line with export-import, administrative reforms to ensure development, achieving growth and eliminating poverty, producing and maintaining quality data, introducing ICT and e-Governance, ensuring free flow of information, project designing, monitoring and evaluation particularly aided project, implementing MTBF and ensuring accountability and transparency in public financial management.

According to the identified items/issues, the most focused current priority received highest score is organization/institution theme followed by service delivery theme, human resource management theme, policy theme, international linkage and relationship theme, financial management theme and project management theme (Annex 14).

\section{Specific areas of knowledge expected to be acquired by the JSs to address the current priorities}

Senior executives were asked to identify specific areas of knowledge (important facts, information, references etc.) they expected to acquire from SSC in order to address the present priorities of the government. They have expected to acquire as many as 27 items/types of knowledge from the SSC in order to address the current priorities of the ministries/organizations. Significant items of knowledge include performance management system, delegation and devolution of power, bi-lateral and multi-lateral negotiation, communicative English, policy planning, policy brief, policy analysis, important government policies, NPM, ICT and e-governance. This knowledge items can be categorized under four thematic areas (Annex 15). The most focused theme is policy followed by service delivery, human resource management and international linkage and relationship.

In order to address the current priorities of the government, respondent Secretaries/Addl. Secretaries suggested as many as 70 items of knowledge required for the Joint Secretaries. Important items of knowledge cover 'current trends of administration and management', 'recruitment and personnel management', 'managing reforms', 'globalization and economic policy', 'English language', 'bi-/multilateral negotiation and regional cooperation', 'PPP', 'international food grain market and the market mechanism', 'basic rules, regulations, procedures of the government', 'Rules of Business and Allocation of Business', 
'Secretariat Instructions', 'relationship between mass media and transparency', 'public policy issues' and 'public asset management', 'policy formulation and drafting', 'policy analysis', 'constitution', 'ICT and e-Governance', 'project management and preparing DPP/TAPP', 'financial management and public procurement procedures'.

Respondent identifies knowledge are mostly related to three thematic areas: such as policy, organization/institution and international linkage and relationship. Other themes include human resource management theme, project management, financial management and service delivery.

\section{Specific area of skills expected to be acquired by the Senior Executives to address the current priorities}

In order to address the current priorities of the ministries/organizations, senior executives have expected to acquire as many as 19 types of skills from the SSC. Noteworthy skills include analytical ability, in-depth review of planning programmes, problem solving, English language, conflict management and negotiation, interpersonal communication skills in multicultural environment, policy formulation and planning, ICT and e-Governance, project management and financial management.

Most of their expected skills are related with international linkage and relationship theme and service delivery. Some of their expected skills are related to policy theme and human resource management theme. Although small, there was concern for financial management skills.

Senior executives further recommended as many as 60 items/types of skills for them. Significant items of skills cover: personnel management, leadership, motivation, team building, communication skills in English language, bi-/multilateral negotiation skills, data presentation, processing and analytical techniques, writing analytical report and summary, coordination and supervision, decision making, seeing things from different dimensions, policy formulation, implementation, monitoring and evaluation, drafting laws rules and regulations, ICT and eGovernance, project management, project impact analysis, SIA, public accounts management.

These skills are again related to seven thematic areas. The most focused theme is inclined with the international linkage and relationship followed by organization/institution and service delivery. Other low score important thematic skills include: human resource management, policy, project management and financial management (Annex 16). 
Rethinking of the Curriculum for the Senior Staff Course of BPATC

\section{Future/long-term priorities of ministries/organizations}

Respondents (senior executives) were asked to identify long term issues/items of government and they further considered 22 issues as future priority areas of their ministries/organizations. Important future priorities include capacity building of union parishad, capacity building of external resource mobilisation, introduction of performance management system in BCS, collection of more grants than loan from donors through non-conventional approach, mass rapid transport, Karnaphuli Tunnel ${ }^{3}$, clustering of ministries, formulation of Civil Service Act and foreign aid policy, e-Governance and e-procurement, and formulation of DPP. These priority areas are closely linked with six thematic areas (Annex 15) such as policy theme, service delivery theme, human resource theme, international linkage and relationship theme, organization and project management themes which are identified as future priority thematic areas of senior executives' ministries/organizations.

Senior executives also identified 73 items of future priorities of their ministries/organizations. The important future priorities include HR planning and merit based recruitment, change management, ensuring supply of quality textile technologists, PPP, diversification of export basket, bi-lateral/multilateral negotiation, WTO, strengthening of BBS, establishing, developing, managing and operating economic zones, development of power and gas sector, administrative reform, clustering ministries, enhancing use of jute and jute products, climate change, reviewing and updating government. policies, formulating appropriate and comprehensive trade policies to safeguard and develop domestic industry, IT policy, social safety nets, ICT and e-governance, digitization of land records, rule of law, accountability and eradication of corruption, good governance, capacity building in project management and continuation of the projects, accelerating inclusive growth and maintaining macro-fiscal stability, domestic revenue mobilization and bringing down fiscal deficit and efficient management of public debt.

In respect to thematic classification of future priorities Annex 17 shows that service delivery is the most important future priority area followed by policy. Other thematic priority areas include international linkage and relationship theme, organization/institution theme, human resource theme, project management theme, and financial management.

${ }^{3}$ A multilane tunnel under the river Karnaphul to connect the southern part of the Chittagong with the port city as well as to facilitate communication with Cox's Bazar. 


\section{Specific area of knowledge required to address the future priorities}

In order to address the future (long-term) priorities of their ministries/organizations respondent Joint Secretaries expected to obtain 28 types/items of knowledge from the SSC (Annex 18). Important areas of knowledge include local government, bi-/multilateral negotiation, conflict management, globalization, regulatory issues, policy planning, policy brief, policy analysis, good governance, combating corruption, ICT and e-Governance, and e-procurement.

These are again related to six thematic areas (Annex 18). The most focused theme is policy. Other thematic areas are international linkage and relationship, service delivery, human resource, organization and financial management.

In order to address the future priorities of the government, Secretaries/Additional. Secretaries suggested 62 items of knowledge required for the Joint Secretaries. Important knowledge areas cover change management, need assessment of organization and employees, time management, negotiation, aid negotiation, WTO, diversification of product and market, acts, rules and regulation, on line decision making, strengthening of democratic setting by civil servants, national policy making, strategic objective and strategic plan, global warming, climate change, regional water crisis reforms activities, country economic trends and commerce, ICT and e-Governance, project management and risk management, financial management and public procurement.

Identified knowledge items are related to seven thematic areas. These are: 'policy' followed by 'international linkage and relationship' and 'service delivery'. Other thematic areas include 'human resource management', 'organization and institution', 'project management' and 'financial management'.

\section{Validation workshop}

The thematic areas are validated with $54^{\text {th }}$ SSC and $55^{\text {th }}$ SSC participants in two separate workshop organized by the research team at BPATC. In the first validation workshop participants identified five thematic areas (such as: HR, ILR, Organization, Policy and Service delivery), where as in the second validation workshop organized by research team at BPATC with 24 respondents, and they added two more thematic areas (Project management and Financial management), which are same with earlier.

\section{Discussion and findings}

The main focus of the study is to identify the development needs of the senior executives of Bangladesh Civil Service in order to facilitate them with some knowledge and skills through 
the Senior Staff Course so that they can effectively and efficiently address the upcoming unpredictable challenges of the country. Keeping this in view, the study conducted a pilot survey with the participant Joint Secretaries who attended the $54^{\text {th }}$ SSC at BPATC. Based on the findings of the survey, the study collected opinions from selected number of Ministers, advisor to the Prime Minister, officials with the rank and status of Secretary and Additional Secretary to the Government, participant Joint Secretaries of $56^{\text {th }}$ SSC, representatives of international organizations operating in Bangladesh and representatives of CSOs and business organizations. Opinions of the said stakeholders revealed some common tasks usually undertaken by the Joint Secretaries, key current and future priorities of the government, and required knowledge and skills for the Joint Secretaries of BCS in order to materialize those priorities. The study further observed that all of those tasks, priorities, knowledge and skills are directly linked to seven thematic clusters namely 'human resources (HR)', 'international linkage and relationships (ILR)', 'organizations/institutions (ORG)', 'policy', 'service delivery (SD)', 'project management (PM)' and 'financial management (FM)'. Finally, the study validated the findings through conducting two half-day workshops with the participants of 56th and 58th SSC respectively.

Opinions of the stakeholders revealed some common tasks usually undertaken by the Joint Secretaries, key current and future priorities of the government, and required knowledge and skills for the Joint Secretaries of BCS in order to materialize those priorities. From analysis of data we initially got five thematic clusters of issues. Apart from this, this study finding went with two validation workshop with the participants of $56^{\text {th }}$ and $58^{\text {th }}$ SSC respectively. Validation findings are also related with seven thematic clusters such as: 'HR', 'ILR', 'ORG', 'policy', 'SD', 'PM' and 'FM'.

\section{Conclusions}

The Senior Staff Course is undergoing a process of change to enable the course to take account of a rapidly changing world which, in turn, influences the pace of change for Bangladesh. These changes, plus many internal threats to the livelihood and wellbeing of our citizens, need to be addressed more effectively. Otherwise, ability of Bangladesh to provide safety, health and adequate quality of life of all its citizens will continue to be severely impaired. It is the Senior Civil Servants, especially the Joint Secretaries of BCS who can play a vital role in furthering development goals and ensuring services to meet the needs of the citizens.

The findings of the study show that senior executives are involved in various kinds of functions as they represent different ministries/organizations with diversified priorities. As such, it could be realistic to address their generic needs instead of taking attempts to address

their diversified needs, which is not feasible through a formal course with 45-60 days of 
duration. It is also important to mention that the SSC is, perhaps, the last career development course for a Joint Secretary before being promoted to the position of an Additional Secretary and subsequently a Secretary. Therefore, the Senior Staff Course would facilitate the Joint Secretaries to prepare themselves for the highest position in BCS. They have to develop holistic view about development perspectives of the country with critical understanding of public policies, organization development and human resource management, bi-/multilateral negotiation, citizen centric service delivery, development programme management and optimal use of public spending. The SSC would facilitate the participants with theoretical issues but thrust could be given to the delivery of contents through participatory methods instead of traditional lecture methods. Each participant should also be given at least three individual assignments connected to his/her own organizational policy, service delivery and bi/multilateral issues.

The study findings further indicate that in order to prepare them for the highest position in BCS, the Joint Secretaries should have command on analysis and presentation. Therefore, Joint Secretaries of BCS have to explore, exploit, experiment and explain the information required for the Ministries/Organizations. As per thematic areas there are seven thematic clusters such as 'HR', 'ILR', 'ORG', 'Policy', 'SD', 'PM' and FM'.

In order to better assess the current and future development needs of the participants of the SSCs related to these issues of change, the findings of the study indicate some essential knowledge and skills relating to seven basic themes which appear to be important as key focus areas of future SSC programmes. In addition, contents and delivery methods need to be very appropriate and time to time update is essential.

\section{References}

Ahmed, S. (2010). Rising tides. Forum, a Monthly Publication of The Daily Star, 3(2).

BPATC. (2009). Course guidelines: Fifty-first senior staff course. Dhaka: BPATC

GOB. (2003). Public Administration Training Policy. Dhaka: Ministry of Public Administration.

Haque, M. S. (2001). Pride and performance in the public service: Three Asian cases. International Review of Administrative Sciences, Vol. 67, pp. 99-115.

Hossain, E. \& Imam, K. H. (2002). Curriculum Development of Senior Staff Course. , BPATC, Dhaka.

Jahan, F. (2006). Public Administration in Bangladesh. CGS Working Paper1. Dhaka: BRAC University.

Wahiduzzaman, M. (1989.) Assessment of Training Needs of Senior Civil Servant: A case study. Dhaka: BPATC 
World Bank (1996). Government That Works - Reforming the Public Sector. Dhaka: University Press.

Zafarullah, H., Khan, M.M. \& Rahman, M.H. (1997). Civil service systems: Bangladesh. Paper prepared for the conference on Civil Service Systems in Comparative Perspective, School of Public and Environmental Affairs, Indiana University, Bloomington, Indiana, 5-8 April 1997. 


\section{Annexure}

Annex 1: Place of posting of the respondents

\begin{tabular}{lc}
\hline Place of Posting & Number \\
\hline BADC & 1 \\
ERD & 1 \\
BTMC & 1 \\
BIWTC & 1 \\
Department of Youth Development & 1 \\
National Housing Authority & 1 \\
Dhaka WASA & 1 \\
M/O Health and Family Welfare & 1 \\
BSCIC & 1 \\
NHRC & 1 \\
M/O Land & 1 \\
Bangladesh Handloom Board & 1 \\
M/O Information & 1 \\
National Museum of Science and Technology & 1 \\
PetroBangla & 1 \\
One House One Farm Project & 1 \\
Rangpur Cantonment & 1 \\
BTC, Ministry Commerce & 1 \\
\hline Total & 18 \\
\hline
\end{tabular}

Annex 2: Length of service at present position

\begin{tabular}{lcc}
\hline Length of service & Number & $\%$ \\
\hline $01-02$ years & 12 & 66.7 \\
02-03 years and above & 6 & 33.3 \\
\hline Total & 18 & 100.00 \\
\hline
\end{tabular}


Rethinking of the Curriculum for the Senior Staff Course of BPATC

Annex 3: Field of experience related to official duties

\begin{tabular}{lc}
\hline Major areas of field experience & Number \\
\hline Field Administration & 9 \\
Personnel Management & 4 \\
Financial Management & 2 \\
Regulatory issues & 2 \\
Policy formulation/ drafting & 2 \\
Project Management & 1 \\
Land Management & 1 \\
Bi-/Multilateral Negotiation & 1 \\
International commerce & 1 \\
\hline Multiple responses recorded. &
\end{tabular}

Annex 4: Common and specific tasks

\begin{tabular}{lclc}
\hline Tasks at official capacity & Number & Major themes & $\begin{array}{c}\text { Thematic cluster } \\
\text { sum }\end{array}$ \\
\hline Administrative work & 14 & HR & 20 \\
HRM/HRD & 6 & HR & 3 \\
$\begin{array}{l}\text { Negotiation with development } \\
\text { partners }\end{array}$ & 3 & ILR & 3 \\
$\begin{array}{l}\text { Protocol } \\
\text { Policy formulation and advocacy }\end{array}$ & 3 & ORG & \\
Land acquisition & 2 & POLICY & \\
Laws, rules and regulations & 1 & POLICY & 4 \\
& 1 & POLICY & 5 \\
Project management & 5 & PM & 5 \\
Finance and audit & 4 & FM & \\
Customs and VAT & 1 & FM & \\
Multiple responses recorded. & & \\
HR-Human Resource; ORG-organization; ILR-International Linkage and Relationship; FM- \\
Financial Management; PM-Project Management.
\end{tabular}


Rethinking of the Curriculum for the Senior Staff Course of BPATC

Table 5: Current priorities to government

\begin{tabular}{llll}
\hline Major areas of priorities & Number & Major theme & $\begin{array}{c}\text { Thematic cluster } \\
\text { sum }\end{array}$ \\
\hline Education and HRD & 8 & HR & 10 \\
Employment generation & 2 & HR & \\
Poverty alleviation & 9 & POLICY & \\
Energy security & 8 & POLICY & \\
Population control & 5 & POLICY & \\
Disaster management & 4 & POLICY & \\
Self-sufficiency in food production & 2 & POLICY & \\
infrastructure development & 3 & POLICY & \\
Reform in civil service & 1 & POLICY & \\
Agricultural development & 2 & POLICY & \\
Environmental & 2 & POLICY & \\
change & & & \\
Strengthening local government & 2 & ORG & \\
Price control of essential commodities & 4 & FM & \\
Traffic control in Dhaka City & 1 & SD & \\
Improvement of water resources & 1 & SD & \\
Reduced corruption & 3 & SD & \\
Law and Order & 2 & SD & \\
Food security & 1 & SD & \\
ICT and E-governance & 16 & SD & \\
Effective public service delivery & 1 & SD & \\
\hline
\end{tabular}

Note: SD-Service Delivery 
Annex 6: Future priorities for the government

\begin{tabular}{lllc}
\hline Future priority areas & Number & $\begin{array}{l}\text { Major } \\
\text { themes }\end{array}$ & Thematic cluster sum \\
\hline Market-based salary for public servant & 1 & HR & \\
$\begin{array}{l}\text { Education and HRD } \\
\text { Skills for overseas employment }\end{array}$ & 6 & HR & \\
Employment generation & 2 & HR & 12 \\
& 3 & HR & 2 \\
Strengthening local government & & & \\
PPP & 1 & ORG & \\
Infrastructure & 2 & ILR & \\
Power and energy & 2 & POLICY & \\
Climate change & 8 & POLICY & \\
Population control & 2 & POLICY & \\
Social security and justice & 2 & POLICY & \\
Land use policy & 4 & POLICY & \\
Extraction of natural resources & 2 & POLICY & \\
Water Resources & 1 & POLICY & \\
Making Bangladesh $\quad$ a developed & 1 & POLICY & \\
country & 1 & POLICY & \\
Decentralising administration & & & \\
Breaking syndicate & 2 & POLICY & \\
Food security & 2 & SD & \\
Law and order & 2 & SD & \\
ICT and e-governance & 4 & SD & \\
Reducing corruption & 8 & SD & \\
Good governance & 1 & SD & \\
\hline
\end{tabular}

Multiple responses recorded. 
Annex 7: Knowledge expected to obtain from SSC

\begin{tabular}{|c|c|c|c|}
\hline Areas of Knowledge & Number & $\begin{array}{l}\text { Major } \\
\text { themes }\end{array}$ & $\begin{array}{c}\text { Thematic } \\
\text { cluster sum }\end{array}$ \\
\hline Rules and laws and draft recommendation & 1 & HR & \\
\hline Competency framework & 1 & HR & \\
\hline Tools for professionalism & 1 & HR & \\
\hline Strategic management & 1 & HR & 4 \\
\hline Bi-/Multilateral negotiation & 6 & ILR & \\
\hline Communicative English & 1 & ILR & \\
\hline PPP & 1 & ILR & 8 \\
\hline Important public policies & 4 & POLICY & \\
\hline Policy reform and policy formulation & 5 & POLICY & \\
\hline $\begin{array}{l}\text { Development administration and governance } \\
\text { studies }\end{array}$ & 3 & POLICY & \\
\hline $\begin{array}{l}\text { Development economics and economic } \\
\text { policies }\end{array}$ & 4 & POLICY & \\
\hline Climate change & 1 & POLICY & \\
\hline Prudential uses of natural resources & 1 & POLICY & \\
\hline Effects of migration & 1 & POLICY & 19 \\
\hline Quick delivery of services & 1 & SD & \\
\hline TQM & 1 & SD & \\
\hline ICT and E-governance & 9 & SD & 11 \\
\hline Public procurement & 1 & FM & \\
\hline Fiscal policy & 1 & FM & 2 \\
\hline
\end{tabular}


Rethinking of the Curriculum for the Senior Staff Course of BPATC

Annex 8: Skills expected to obtain from SSC

\begin{tabular}{lclc}
\hline Expected skill area & Number & Major theme & $\begin{array}{c}\text { Thematic } \\
\text { cluster sum }\end{array}$ \\
\hline Management and motivational skill & 3 & HR & 4 \\
$\begin{array}{l}\text { Performance based management } \\
\text { Negotiation skill with development partner }\end{array}$ & 7 & HR & \\
Communicative English & 4 & ILR & 11 \\
Leadership skill & 2 & ORG & \\
Writing report and minutes & 1 & ORG & 12 \\
Decision making and problem solving skill & 5 & ORG & 6 \\
Policy drafting and framing & 6 & POLICY & \\
ICT & 6 & SD & 7 \\
TQM & 1 & SD & 1 \\
Project evaluation and implementation & 1 & PM & 4 \\
Public procurement & 4 & FM & \\
\hline
\end{tabular}

Multiple responses recorded. 
Annex 9: Organizational needs for improving better service

\begin{tabular}{|c|c|c|c|}
\hline Organizational need & Number & $\begin{array}{l}\text { Major } \\
\text { theme }\end{array}$ & $\begin{array}{l}\text { Thematic cluster } \\
\text { sum }\end{array}$ \\
\hline Results based performance & 2 & HR & 2 \\
\hline Documentation and record keeping & 1 & ORG & \\
\hline Vessel maintenance & 1 & ORG & \\
\hline $\begin{array}{l}\text { Service rules of Petro Bangla and its } \\
\text { labour union and CBA }\end{array}$ & 1 & ORG & \\
\hline $\begin{array}{l}\text { Industrial data base to meet-up the } \\
\text { queries in time }\end{array}$ & 1 & ORG & 4 \\
\hline $\begin{array}{l}\text { Speedy disposal of issues and } \\
\text { complaints }\end{array}$ & 3 & SD & \\
\hline Office automation & 9 & SD & \\
\hline Citizen centric service & 3 & SD & \\
\hline $\begin{array}{l}\text { Performance of small and cottage } \\
\text { industry }\end{array}$ & 1 & SD & 16 \\
\hline Audit objection & 1 & FM & \\
\hline $\begin{array}{l}\text { Financial management and budgetary } \\
\text { system }\end{array}$ & 2 & FM & \\
\hline Public procurement procedure & 2 & FM & 5 \\
\hline
\end{tabular}

Multiple responses recorded. 
Rethinking of the Curriculum for the Senior Staff Course of BPATC

Annex 10: Experience related to official duties

\begin{tabular}{lll}
\hline Fields of experiences & $\begin{array}{l}\text { Joint Secretaries } \\
(\mathrm{N}=20)\end{array}$ & $\begin{array}{l}\text { Secretary and Additional } \\
\text { Secretaries (N=33) }\end{array}$ \\
\hline Project management & $9(45.0)$ & $19(57.58)$ \\
Financial management & $7(35.0)$ & $16(48.48)$ \\
Personnel management & $12(60.0)$ & $16(48.48)$ \\
Land management & $2(10.0)$ & $13(39.39)$ \\
E-governance & $2(10.0)$ & $9(27.27)$ \\
Regulatory issues & $4(20.0)$ & $11(33.33)$ \\
Bi-/multilateral negotiation & $1(5.0)$ & $9(27.27)$ \\
Policy formulation/drafting & $7(35.0)$ & $13(39.39)$ \\
International commerce & 00.00 & 0 \\
Field administration & $13(65.0)$ & $9(27.27)$ \\
Others (public procurement; career & & \\
planning; mass communication; & \\
population studies; TQM; training & \\
management; training and & & \\
development; media) & & \\
\hline
\end{tabular}

Multiple responses recorded. Parenthesis show percentage

Annex 11: Most important routine tasks performed by the respondents

\begin{tabular}{lccc}
\hline Regular task & $\begin{array}{c}\text { Joint Secretaries } \\
(\mathrm{N}=17)\end{array}$ & $\begin{array}{c}\text { Secretary and Additional } \\
\text { Secretaries }(\mathrm{N}=33)\end{array}$ & $\begin{array}{c}\text { Total } \\
(\mathrm{N}=50)\end{array}$ \\
\hline HR & 9 & 34 & 43 \\
ILR & 1 & 12 & 13 \\
Organization & 3 & 24 & 28 \\
Policy & 2 & 22 & 24 \\
Service delivery & 1 & 0 & 1 \\
Project management & 7 & 8 & 15 \\
Financial management & 6 & 7 & 13 \\
\hline Multiple responses recorded. & HR=Human & Resource, ILR=International & Linkage and \\
Relationship/Negotiation, PM= Project Management, FM=Financial Management. &
\end{tabular}


Rethinking of the Curriculum for the Senior Staff Course of BPATC

Annex 12: Common tasks performed by a Joint Secretary

\begin{tabular}{lc}
\hline Task & Score (N=50) \\
\hline Human resource & 34 \\
International linkage and relationship & 12 \\
Organization/institution & 24 \\
Policy & 22 \\
Project management & 8 \\
Financial management & 7 \\
\hline
\end{tabular}

Multiple responses recorded.

Annex 13: Current/short-term (one year) priorities of the ministry /organization

\begin{tabular}{lccc}
\hline Current Priorities & $\begin{array}{c}\text { Joint Secretaries } \\
(\mathrm{N}=17)\end{array}$ & $\begin{array}{c}\text { Secretary and Additional } \\
\text { Secretaries }(\mathrm{N}=33)\end{array}$ & $\begin{array}{c}\text { Total } \\
(\mathrm{N}=50)\end{array}$ \\
\hline Service delivery & 6 & 19 & 25 \\
Policy & 7 & 16 & 23 \\
HR & 5 & 17 & 22 \\
Organization & 0 & 21 & 21 \\
ILR & 6 & 6 & 12 \\
Project management & 2 & 3 & 5 \\
Financial management & 0 & 5 & 5 \\
\hline Multiple responses recorded. & HR=Human & Resource, ILR=International & Linkage and \\
Relationship/Negotiation, PM=Project Management, FM=Financial Management. &
\end{tabular}

Annex 14: Most focused current priorities identified by senior executives

\begin{tabular}{lc}
\hline Priorities & Score $(\mathrm{N}=50)$ \\
\hline Organization/Institution & 21 \\
Service delivery & 19 \\
Human resource & 17 \\
Policy & 16 \\
International linkage and relationship & 6 \\
Financial management & 5 \\
Project management & 3 \\
\hline
\end{tabular}


Rethinking of the Curriculum for the Senior Staff Course of BPATC

Annex: 15: Specific areas of knowledge required to address the present priorities

\begin{tabular}{ll}
\hline Knowledge required to address current priorities & Score $(\mathrm{N}=53)$ \\
\hline International linkage and relationship & 39 \\
Organization/Institution & 24 \\
Service delivery & 18 \\
Human resource & 13 \\
Policy & 11 \\
Project management & 6 \\
Financial management & 5 \\
\hline
\end{tabular}

Multiple responses recorded.

Annex 16: Specific area of skills required to address the current priorities

\begin{tabular}{lcccc}
\hline $\begin{array}{l}\text { Skills required to address } \\
\text { current priorities }\end{array}$ & $\begin{array}{c}\text { Joint Secretaries } \\
(\mathrm{N}=20)\end{array}$ & $\begin{array}{c}\text { Secretary and } \\
\text { Additional Secretaries } \\
(\mathrm{N}=33)\end{array}$ & $\begin{array}{c}\text { Total } \\
(\mathrm{N}=53)\end{array}$ \\
\hline $\begin{array}{l}\text { International linkage } \\
\text { relationship }\end{array}$ & and & 14 & 39 & 53 \\
Service delivery & 11 & 18 & 29 \\
Organization & 0 & 24 & 24 \\
Policy & 7 & 11 & 18 \\
Human resource & 4 & 13 & 6 \\
Project management & 0 & 6 & 6 \\
Financial management & 1 & 5 & \\
\hline
\end{tabular}

Multiple responses recorded. 
Rethinking of the Curriculum for the Senior Staff Course of BPATC

Annex 17: Future priorities of the ministries/organizations

\begin{tabular}{lccc}
\hline Future Priorities & $\begin{array}{c}\text { Joint Secretaries } \\
(\mathrm{N}=17)\end{array}$ & $\begin{array}{c}\text { Secretary and } \\
\text { Additional Secretaries } \\
(\mathrm{N}=33)\end{array}$ & $\begin{array}{c}\text { Total } \\
(\mathrm{N}=50)\end{array}$ \\
\hline Service delivery & 5 & 26 & 31 \\
$\begin{array}{l}\text { Policy } \\
\text { International linkage }\end{array}$ & 6 & 24 & 30 \\
relationship & 3 & 12 & 15 \\
Organization & & & \\
Human resource & 2 & 10 & 12 \\
Project management & 4 & 6 & 10 \\
Financial management & 1 & 4 & 5 \\
\hline
\end{tabular}

Multiple responses recorded.

Annex 18: Specific areas of knowledge required to address the future priorities

\begin{tabular}{|c|c|c|c|}
\hline Theme area of knowledge & $\begin{array}{c}\text { Joint Secretaries } \\
\qquad(\mathrm{N}=20)\end{array}$ & $\begin{array}{c}\text { Secretary and } \\
\text { Additional Secretaries } \\
(\mathrm{N}=33)\end{array}$ & $\begin{array}{c}\text { Total } \\
(\mathrm{N}=53)\end{array}$ \\
\hline Policy & 19 & 34 & 53 \\
\hline $\begin{array}{l}\text { International linkage and } \\
\text { relationship }\end{array}$ & 10 & 10 & 20 \\
\hline Service delivery & 10 & 10 & 20 \\
\hline Human resource & 2 & 9 & 11 \\
\hline Organization & 1 & 9 & 10 \\
\hline Project management & 0 & 6 & 6 \\
\hline Financial management & 1 & 2 & 3 \\
\hline
\end{tabular}

Multiple responses recorded. 